\title{
Community Characteristics and Coexistence of Four Medicinally Important Plants in Quercus Leucotrichophora A. Camus Forest of Central Himalaya, India.
}

\section{Poonam Prasad}

Kumaun University

Jeet Ram ( $\sim$ jeetram2001@yahoo.com )

Department of Forestry \& Environmental Science, Kumaun University, Nainital, Uttarakhand, India.

\section{Beena Tewari}

Kumaun University

\section{Research}

Keywords: Oak, Interspecific association, Frequency, Importance Value, Uttarakhand

Posted Date: October 15th, 2020

DOI: https://doi.org/10.21203/rs.3.rs-91186/v1

License: (c) (1) This work is licensed under a Creative Commons Attribution 4.0 International License.

Read Full License 
Community characteristics and coexistence of four medicinally important plants in Quercus leucotrichophora A. Camus forest of Central Himalaya, India.

Poonam Prasad, Jeet Ram* and Beena Tewari

Department of Forestry \& Environmental Science, Kumaun University, Nainital, Uttarakhand, India. *Correspondence: jeetram2001@yahoo.com 


\begin{abstract}
Background: The Quercus leucotrichophora is a keystone species in maintaining the biodiversity of several other species and provides ecosystem service to the people residing around the forest. The present study is to investigate the community characteristic and coexistence of four medicinally important plants species viz. Boenninghausenia albiflora (Hk.) Reichb. ExMeissn. Hedychium spicatum (Ham. Ex Smith), Origanum vulgare (Linn.) and Rubia manjith (Linn.) in Quercus leucotrichophora forest in different canopies at three different sites i.e. Hanumangarh, Kailakhan and Pines in the Central Himalaya.

Results: In the present study, a total of 81 herbaceous species encountered in the sample, out of which 41 species showed Importance Value Index (IVI) $\geq 5$. About 50\% species were common in different sites whereas about $54 \%$ species were common in different canopies. There was variation in species richness among the sites (52-67 species), whereas, amongst the canopies, species richness was higher in open canopy and least in close canopy. The co-existence between the selected four species showed a frequency distribution $<60 \%$ indicating their presence as rare, seldom or often. Amongst the sites, Boenninghausenia albiflora and Origanum vulgare showed its dominance in Pines, Hedychium spicatum at Kailakhan and Rubia manjith at Hanumangarh site. The coexistence between Origanum vulgare and other three species viz. Boenninghausenia albiflora, Rubia manjith and Hedychium spicatum showed negative values, while Boenninghausenia albiflora and two other species viz. Rubia manjith, Hedychium spicatum and Rubia manjith \& Hedychium spicatum showed positive coefficient of association. The chi-square in both the cases indicated the values are non-significant resulting not a strong coexistence in the Oak forest, therefore their occurrence together in the community might be by chance.

Conclusion: The growth of species in different habitat and association of medicinal plants is important in identifying the suitable habitat and canopy toward future multiplication of the different species in the Himalayan region. The finding of the present study would be also helpful to develop the structure and adequate strategy \& plan for conservation and management of habitats, species and communities for their sustainable utilization in different part of the world.
\end{abstract}

Keywords Oak, Interspecific association, Frequency, Importance Value, Uttarakhand 


\section{Background}

The Himalaya spread over a large area in the Northern part of India and rich in vegetation composition. The five different species of oak are distributed from mid to high elevation areas and form the dominant forest in the Central Himalayan region. Quercus leucotrichophora is one of the keystone species which maintains the biodiversity of many other species. Banj Oak (Quercus leucotrichophora A.Camus) forest is distributed between 1500m to about $2200 \mathrm{~m}$ elevation and most of the human population distributed in this mountain part of the India. Plant community plays an essential role in enduring management by maintaining biodiversity and conserving the environment (Farooquee and Saxena 1996; Arya 2014). Ecological communities are structured by complex networks of organisms and species interactions (Pamela et al. 2007). The structure and function of Himalayan forest was studied by various workers (Saxena and Singh 1982; Saxena et al. 1984; Upreti et al. 1985; Singh and Singh 1992; Singh et al. 1994; Rathore et al. 1997; Khera et al. 2001; Ram et al. 2004; Kumar and Ram 2005; Hussain et al. 2008; Gairola et al. 2011; Bargali et al. 2015; Singh et al. 2016; Tiwari et al. 2018; Sati and Bandooni 2018) from time to time. This forest consists the large number of herbaceous species used by the local people for various purposes. The oak forest provides numerous ecosystems services and also serve as a lifeline for the local communities (Singh and Singh 1984). The continued human onslaughts on these forests leads different stages of degradation. Vegetation ecology includes the study of species composition and sociological association of species in communities (Mueller- Dombois and Ellenberg 1974). Vegetation, in its entirety, as well as the individual species as indicators are equally considered to be specific subjects for studying the levels of the critical loads of ecosystems (Burianek et al. 2013). It also plays the fundamental role in the maintenance of biodiversity (Altieri 1994; Stang et al. 2007; Zhang 2012a; Jayakumar et al. 2011; Ahmad et al. 2013) and helpful in assessment of ground vegetation monitoring and constitutes an acknowledged basis for biodiversity assessment (Neumann and Starlinger 2001; Petriccione 2002; Seidling 2005; Salemaa and Hamberg 2007; Burianek et al. 2013).

The interspecific association of plant species were studied by Hurlbert (1969); Connor and Simberloff (1979) Schluter (1984); Oliveira et al. (2007); Zhang et al. (2014); Yang et al. (2016); Gu et al. (2017); and Sanjerehei and Rundel (2020). Species interactions are of central importance in the ecology of a species. Biotic interactions (niche partitioning, limiting similarity) that prevent coexisting species from being too similar is among the most important and best studied of these processes (MacArthur and Levins 1967; Chesson 2000; Yuan 2016). At high density, plants may experience strong intraspecific competition for both aboveground (e.g., light) and belowground (e.g., soil 
nutrients) resources which results in decreased growth, reduced leaf nutrient content and lowered defenses against herbivores (Crawley 1989; Kula et al. 2020). Two species have some mutual attraction, repulsion, or no interaction in a community. Therefore, the association may be positive, negative or absent (Dixon 1994; Pielou 1961). Positive interaction between plant species are widespread in natural communities and have been acknowledged as a major driver of plant community dynamics and ecosystem processes (Bruno et al. 2003). Positive association indicates facilitation, while negative association indicates competition between two species (Sanjerehei and Rundel 2020). We considered the co-existence of species as positive association and absence of co-existence is as negative or no association. There are many measures for interspecific association, including $\boldsymbol{x}^{2}$ test, variance ratio method, coupling coefficient, co-occurrence percentage, point correlation, the similarity percentage for distribution, Spearman rank correlation, Pearson correlation, etc. (Schoenly and Zhang 1999; Zhang 2007, 2011, 2012a, 2012b). Community structure spatial distribution pattern, co-existence of plant species, community assembly and interspecific associations were analyzed for grass community and medicinal plant species by different workers (Goodall 1953, Hurlbert 1969, Ratliff 1982, Weiher et al. 1998, Oliveira et al. 2007, Zhang 2014, Dice 1945, Correia et al. 2010, Chang and Lambers 2019). However, there is little or no studies were carried out in the region on this aspect. Thus, the aim of the present study is to investigate the community characteristics and coexistence of four medicinally important plants in Quercus leucotrichophora forest.

\section{Material and Methods}

\section{Study area}

The study area lies between $29^{\circ} 21^{\prime} \mathrm{N}$ and $29^{\circ} 23^{\prime} \mathrm{N}$ latitude and $79^{\circ} 27^{\prime} \mathrm{E}$ and $79^{\circ} 29^{\prime} \mathrm{E}$ longitude between 1800 to 1950 m elevation in Uttarakhand Central Himalaya (Fig. 1). The aspect of the study area falls in North East and East aspect with $Q$. leucotrichophora as the dominant tree species. The climate of the study area is influenced by monsoon pattern of rainfall. The annual rainfall was $2821 \mathrm{~mm}$ of which three fourth occurred during rainy season (mid-June to mid-September). The mean monthly maximum temperature ranged between $16.8^{\circ} \mathrm{C}$ (January) and $29{ }^{\circ} \mathrm{C}$ (May) and mean minimum temperature ranged between $1.2{ }^{\circ} \mathrm{C}$ (January) and $14{ }^{\circ} \mathrm{C}$ (June) (Khera et al. 2001). The rocks of the study area are mainly sandstones, conglomeration, limestone, quartzite, schist's and granites (Valdiya 1980). In this study area, the Banj Oak is the dominant (IVI > 70\%) forest forming species and other some species are also associated viz. Myrica esculenta Buch. -Ham.ex D. Don, Rhododendron arboretum Sm., and Acer oblongum Wall. Ex DC., 
Pinus roxburghii Sarg., Cedrus deodara (Roxb.ex D.Don) D.Don., Quercus lanata Sm. and Quercus floribunda Lindl.

Ex A.Camus etc. These forest witnesses the chronic form of disturbances where people extract a small amount of bioresources from the forest and do not provide time for ecosystem recovery. The vegetation of oak forest besides other uses, many herb species are medicinally important and are used by the local people for the cure of several diseases. Four medicinally important plant species i.e Boenninghausenia albiflora (Hk.) Reichb. ExMeissn. Hedychium spicatum (Ham. Ex Smith), Origanum vulgare (Linn.) and Rubia manjith (Linn.) present in the study area were selected for the study. These species distributed in the Himalaya from subtropical to temperate region and the IUCN Red list indicated that all the four medicinally important species are under threatened category Table 1

Fig. 1. Location map of the study area

Table 1. Description of selected medicinal plant species.

\section{Methodology}

After thorough reconnaissance of the area, three sites were selected for the detail study of vegetation characteristics and association of important medicinal plants. The size and number of the sample were determined following Saxena and Singh (1982). In each site, line transects of $10 \mathrm{~m}$ were randomly placed to determine the crown cover of the forest and categorized as open canopied forest $(<40 \%)$, moderate canopied forest $(40-70 \%)$ and close canopied forest (>70\%). In each canopy, 10 quadrats of $1 \mathrm{x} 1 \mathrm{~m}$ were randomly placed on the ground for assessment of herb vegetation and thus a total of 30 samples in each site were studied. The herb cover was determined by placing 10 line transect of $1 \mathrm{~m}$ and percent area occupied by each species was noted avoiding overlap (Misra 1968). The vegetation parameters were quantitatively analyzed for density, frequency and abundance (Curtis and McIntosh 1950). The Importance Value Index (IVI) for herbs was determined as the sum of relative density, relative frequency and relative dominance (Philips 1959). These vegetation parameters were used to determine the relative importance of the species in different canopies and sites.

The presence and absence of medicinal plant species in different canopy cover was determined following Raunkiaer, (1934), where 1-20, was considered Rare; 21-40, Seldom present; 41-60, Often present; 61-80, Mostly present; and 
81-100, Constantly present. The percent contribution of these medicinal plant species in the community was determined by the following equations (a-c).

Percent Density $=\frac{\text { Density of a plant species }}{\text { Total density of all species }} X 100$

Percent Total cover $=\frac{\text { cover of a plant species }}{\text { Total cover of all spcies }} X 100$

Percent IVI $=\frac{\text { IVI of a plant species }}{\text { Total IVI of all species }} X 100$

The Coefficients of interspecific association was calculated from unit-area (quadrat) sampling data. A total 270 samples were studied in each site for determination of coexistence of species. The presence-absence data of a species were obtained using quadrats of $1 \mathrm{x} 1 \mathrm{~m}$. The coefficient of association was determined based on presence or absence of four medicinally important plant in different samples (quadrats). The data were summarized in a 2 x 2 contingency table as (Cole's 1949; Hurlbert 1969; Ratliff 1982) in the Table 2.

Table 2. Calculation table for coefficient of interspecific association

To construct this table, the sampling units were examined for presence or absence of both species (A and B). The number of samples containing both A and B is designated (a), only species A is present (b), only species B is present (c), and both species A and B Absent (d). From these data, a coefficient of association (Cole devised $\mathrm{C}_{7}$ ), varying from +1.0 for a condition of maximum possible co-occurrence of species to -1.0 for a condition of minimum possible cooccurrence, is calculated. A value of 0 for this coefficient indicates that the frequency of co-occurrence is that expected by chance. The equations used to determine the coefficient of association are as follows (Cole's 1949; Hurlbert 1969; Ratliff 1982).

If $\mathrm{ad} \geq \mathrm{bc}$ and $\mathrm{c}<\mathrm{b}$, then $\quad \mathrm{C}_{7}=\frac{a d-b c}{(a+b)(b+d)}$
If $\mathrm{ad} \geq \mathrm{bc}$ and $\mathrm{c} \geq \mathrm{b}$, then $\quad \mathrm{C}_{7}=\frac{a d-b c}{(a+c)(c+d)}$ 


$$
\begin{aligned}
& \text { If } \mathrm{ad}<\mathrm{bc} \text { and } \mathrm{a} \leq \mathrm{d} \text {, then } \quad \mathrm{C}_{7}=\frac{a d-b c}{(a+b)(a+c)} \\
& \text { If } \mathrm{ad}<\mathrm{bc} \text { and } \mathrm{a}>\mathrm{d} \text {, then } \quad \mathrm{C}_{7}=\frac{a d-b c}{(b+d)(c+d)}
\end{aligned}
$$

The pairing of 4 species is made by taking two species at a time i.e. Boenninghusania albiflora x Hedychium spicatum, Boenninghausenia albiflora x Origanum vulgare, Boenninghausenia albiflora x Rubia manjith, Hedychium spicatum x Origanum vulgare, Hedychium spicatum x Rubia manjith, and Origanum vulgare x Rubia manjith. The Chi $\left(\chi^{2}\right)$ test was applied to determine the significance of the association between the species pair following Hurlbert (1969).

$\chi 2=\frac{(a d-b c)^{2} * n}{(a+b)(a+c)(b+d)(c+d)}$

If the calculated value of Chi $\left(\chi^{2}\right)$ is greater than tabulated value, the difference is considered as significant $(<0.05)$ and lesser value indicated the insignificance. The data of total density, cover and IVI were analyzed for Analysis of Variance (ANOVA). Least significant difference was also determined for the significance among the canopy and sites (Snedecor and Cochran 1967).

\section{Results}

\section{Species Importance}

Large number of species contributed to the herbaceous layer of Quercus leucotrichophora forest. A total of 81 herbaceous species were encountered in the samples laid down in oak forest. Out of 81 species encountered in the sample, 67 species were present in Hanumangarh, 52 species in Kailakhan and 59 species in Pines. Similarly, in Open canopy 71 species were present followed by Moderate (61 species) and close canopy (51 species). We have considered importance value of those species having IVI $\geq 5$ in different canopies of a site. Thus, a total of 41 species showed IVI $\geq 5$ (Table 3). In Hanumangarh, the most important herb species was Erigeron karvinskianus (IVI=72.16) in open canopy, followed by Oplismenus undulatifolius (IVI=52.91) in close canopy. While, in moderate canopy Carex condensata showed its dominance (IVI=47.04). In Kailakhan, the most important herb species was Oplismenus undulatifolius (IVI=74.99) in moderate canopy as well as in close canopy (IVI=68.15). While, in open canopy, Capillipedium assimile was the most dominant (IVI=65.53) species. In Pines, the most important species was Erigeron 
karvinskianus (IVI=54.44) in open canopy followed by Ophiopogon intermedius (IVI= 44.10) in moderate canopy. While, Carex condensata (IVI=43.06) was dominant in close canopy.

Table 3. Species Importance Value Index under different sites and canopies

\section{Species frequency}

The presence and absence of four medicinal plants viz. Boenninghausenia albiflora, Hedychium spicatum, Rubia manjith and Origanum vulgare in different samples were determined. All the species showed frequencies $<60 \%$, and none of the species were mostly or constantly present. In Hanumangarh, Hedychium spicatum, Origanum vulgare and Rubia manjith were seldom present with frequency (21-40), while, Boenninghusania albiflora was often present (4160). In Kailakhan, Boenninghusania albiflora, Origanum vulgare and Rubia manjith were seldom present, while, Hedychium spicatum was often present. In Pines, Hedychium spicatum and Origanum vulgare were seldom present, while Boenninghusania albiflora was oftenly present and Rubia manjith was rarely $(<20)$ present in this site (Fig. 2).

Fig. 2. Frequency (Presence-absence) of four medicinally important plants in different Sites

1-20 Rare, 21-40 Seldom present, 41-60 Often present

Across the canopy, Boenninghausenia albiflora indicated that the vegetation density, cover and IVI was higher in moderate and close canopy. Hedychium spicatum showed higher vegetation density, cover and IVI in close canopy. While, Origanum vulgare showed higher value for these vegetation parameters in open to moderate canopy. Rubia manjith showed higher vegetation density, cover and IVI in moderate and close canopy. Across the sites, the vegetation density, cover and IVI for Boenninghausenia albiflora as well as for Origanum vulgare at Pines was having higher values. Hedychium spicatum showed higher value of density, cover and IVI at Kailakhan and Rubia manjith at Hanumangarh (Table $4 \& 5$ ). The analysis of variance (ANOVA) indicated that the density, total cover and IVI were not significantly different across the sites and canopy. The least significant difference was also not significant among the canopy and sites.

Table 4. Variation in vegetation parameters in different sites 
Table 5. Variation in vegetation parameters in different canopy

The contribution of the medicinal plants to the total vegetation density are given in Fig 3 (a-c). All the four medicinal plants contributed very small amount to the vegetation density, cover and IVI. Across the different sites the percent density was maximum at Pines site $(<8)$ followed by Hanumangarh $(<6)$ and Kailkhan $(<5)$ for all the selected species. Among the different canopy the percent density was maximum for Origanum vulgare (5.29) and minimum for Rubia manjith (0.86) in open canopy at Hanumangarh for both the species. While, Hedychium spicatum were absent in open canopy. Whereas, in moderate canopy the density was maximum for Origanum vulgare (6.97) and minimum for Hedychium spicatum (0.35) at Pines. In close canopy percent density were maximum for Boenninghausenia albiflora (7.56) at Pines and minimum for Rubia manjith (0.39) at Kailakhan site. While, Origanum vulgare were absent in close canopy at both Hanumangarh and Kailakhan (Fig. 3a). The percent cover was maximum at Pines $(<20)$ followed by Hanumangarh and Kailkhan $(<7)$ for all the selected species. In open canopy the total percent cover was maximum for Origanum vulgare (6.19) at Hanumangarh and minimum for Rubia manjith (0.10) at Pines. While, Hedychium spicatum were absent in open canopy at Kailakhan. Whereas, in moderate canopy it was maximum for Origanum vulgare (19.78) and minimum for Hedychium spicatum (0.01) at Pines. In close canopy the total percent cover was maximum for Boenninghausenia albiflora (19.98) and minimum for Origanum vulgare (0.07). While, it was absent in Hanumangarh and Kailakhan (Fig. 3b). The percent IVI was maximum at Pines $(<12)$ followed by Hanumangarh and Kailakhan $(<6)$ for all the four species. In open canopy, the percent IVI was maximum for Origanum vulgare (5.33) at Kailakhan and minimum for Rubia manjith (0.53) at Pines. While, Hedychium spicatum were absent in open canopy at Kailakhan. Whereas, in moderate canopy it was maximum for Origanum vulgare (10.57) and minimum for Origanum vulgare (0.36) at Pines and Hanumangarh respectively. In close canopy, the IVI was maximum for Boenninghausenia albiflora (11.57) at Pines and minimum for Rubia manjith (0.37) at Kailakhan. While, Origanum vulgare were absent in Hanumangarh and Kailakhan (Fig. 3c).

Fig 3. The Percent (a) Density (b) Total cover (c) IVI of medicinal plants to the total vegetation in different sites and canopy class 


\section{Coefficient of Association}

The coefficient of association between Origanum vulgare and Boenninghausenia albiflora, Origanum vulgare and Rubia manjith, Origanum vulgare and Hedychium spicatum showed negative value and the chi-square test indicated that this coexistence is not significant. Boenninghausenia albiflora and Rubia manjith, Boenninghausenia albiflora and Hedychium spicatum, Rubia manjith and Hedychium spicatum showed positive coefficient of association but the chi-square test indicated that these values are not significant (Table 6).

Table 6. Coefficient of association \& chi-square values of four medicinally important plants

\section{Discussion}

The Quercus leucotrichophora is a dominated forest forming species in mid elevation mainly between $1000-2000$ $\mathrm{m}$, which is the most populated zone in mountainous part of the Central Himalaya. This species acts as a keystone species which maintain the biodiversity of several other species, and provides several ecosystem services to the people residing around the forest. This led to high pressure on these forests and therefore is at various stages of degradation i.e. close to open forest. The chronic form of disturbances affects the growth and distribution of species as well as biodiversity as whole and some time the recovery of the ecosystem is very difficult. Large number of herbaceous species are present in the oak forest, but not a single herb species showed its clear-cut dominance to the forest floor vegetation. The contribution of individual species to the total Importance value is very low $(<25$ percent), which indicated that the poor dominance of the herbaceous species in the forest and large number of species contributed to the total dominance of the forest floor vegetation. Dicots are the main composition of the forest floor vegetation as compared to monocots. Few grasses and sedge showed its presence in the forest.

Among the sites, the species richness has shown a variation in a range (52-67 species), it was higher at Hanumangarh where human interference was low because the existence of ARIES (Aryabhatta Research Institute of Observational Sciences) compared to other sites. Among the canopy the species richness was high in open canopy and least in close canopy. The open canopy provide abundant sunlight to the forest floor, favors the recruitment of more herbaceous species compared to close canopy. The moderate disturbance like fire and grazing may also favour the recruitment of new species which may resistance to fire or grazing. About 50 percent species were common in different sites whereas about 54 percent species were common in different canopies. The number of restricted species were also varied from 
one site to another as well as one canopy to another (Table 7). The number of restricted species were high (12 species) at Hanumangarh, because of little human interference that provide some protection through the presence of ARIES (Aryabhatta Research Institute of Observational Sciences). The chronic form of disturbances may also responsible for increasing the species richness.

Table 7. Species richness, common species and restricted species in different sites and canopies

The medicinal plants are at the verge of different stages of degradation which influence the frequency and abundance of these species. The frequency of all the four medicinal plants species indicated that these were not mostly and constantly present at the sites. Thus, they were rare, seldom and often present in the community. Boenninghausenia albiflora showed greater dominance in moderate and close canopy compared to open canopy in all the sites. The overall dominance of the species also greater in moderate to close canopy. Whereas, the dominance of Hedychium spicatum was greater in close canopy and Origanum vulgare in open to moderate canopy. The dominance of Rubia manjith was higher in moderate and close canopy. When compared across the sites, Boenninghausenia albiflora and Origanum vulgare showed its dominance in Pines, Hedychium spicatum at Kailakhan and Rubia manjith at Hanumangarh. Thus, it may be concluded that Origanum vulgare grow where sunlight remains sufficient for its growth, whereas, other species grow in moderate to close canopy where they receive some extent of shade. The percent contribution to density, total cover and IVI of all the four medicinal plants were very low in the community.

In many ecological studies, there is a need to express in a quantitative manner the degree to which two different species are associated in nature. A coefficient of association of 1.0 shows that the two species under consideration occur together in exactly the number of sample units expected by chance. A coefficient smaller than 1.0 shows that they occur together in fewer samples than would be expected by chance (Dice 1945). We simply determine the coexistence of four medicinally important plant species in the Quercus leucotrichophora forest. The canopy disturbance creates different ecological conditions in relation to soil, water, humidity, temperature and solar radiation etc. These factors may affect the distribution of herbaceous species.

Interspecific associations in the plant community may help to understand the self-organizing assembly and succession of the community (Zhang 2014). The ability to express quantitatively the extent to which two species do or do not occur (in a series of quadrats, samples, etc.) is a useful tool for the ecologist (Hurlbert 1969). Cole (1949) advised a coefficient of interspecific association $\mathrm{C}_{7}$ which can be assume values from -1 to +1 and this values were used by 
several plant and animal ecologists (Evans and Freeman 1950; Macan 1954; Maguire 1963; Hale 1955; Bray 1956; Vasilevich 1961 \& 1963; Cook and Hurst 1963; Beals 1965; Beaman and Andresen 1966; Smith and Cottam 1967; Hurlbert 1969). In our study Origanum vulgare X Boenninghausenia albiflora, Origanum vulgare X Rubia manjith and Origanum vulgare X Hedychium spicatum showed negative value of coefficient of association which meant that these species grow independently and no definite coexistence was observed between them. Boenninghausenia albiflora X Rubia manjith, Boenninghausenia albiflora X Hedychium spicatum and Rubia manjith X Hedychium spicatum showed positive value of coefficient of association. But the chi square test indicated that the coefficient of association was not significant for the above species pairs. Thus, all the four medicinally important plant species were not showed strong coexistence in the forest floor community of oak forest and their occurrence together in the community were by chance.

The higher herb species richness reported in open canopy was highest followed by moderate and close canopy which was subsequently supported by our previous studies (Prasad and Ram 2017). The herb species richness was recorded for 67 species which was very similar for herbs species in the studies done by Kumar (2000) in Hanumangarh and other forest sites. According to Arya (2012) the opening of canopy in oak forest provides abundant light to the forests floor and triggering the regeneration of many species as well as forest floor vegetation. According to Rikhari et al. (1989), the upper limit of species richness remains higher in considerable altitude upto $2500 \mathrm{~m}$ asl which may be the reason of high richness in Hanumangarh site. The herb richness value reported previously by many workers ranged from 3-414 (Tiwari 1985; Kharkwal et al. 2005) is similar to our values which is highest at Hanumangarh (67 species) and 71 species in Open canopy. According to Pandey et al 2018, higher number of species present at hill top may be due to open canopy which provided chances to species to establish themselves. In our study the dominant species was reported from Asteraceae family in Hanumangarh site, which was supported by Pandey et al. (2018) where maximum herb species were contributed by Asteraceae family.

\section{Conclusion}

The present study provides comprehensive information on site characteristics, habitats, vegetation distribution and species composition including the richness of the important medicinal plants. Most of the medicinal plants are associated with the livelihood of tribal and rural communities living around the forest in Indian Himalaya region. Maintaining good population density as well as diversity of medicinal plants may diffuse the severity of anthropogenic 
pressures. There are reports on decline of medicinal plant populations across the Indian Himalayan region, which is mainly attributed to over-exploitation of these important plant species and habitat degradation. The medicinal plants are at the verge of different stages of degradation which influence the frequency and abundance of these species. The frequency of all the four medicinal plants species indicated that these were not mostly and constantly present at the sites. Thus, they were rare, seldom and often present in the community. The four medicinally important plant species selected in the present study were under IUCN Red list category as threatened species and therefore, preservation and conservation of these species is important. The information on distribution and density of species may help design and redesign forest management practices. The canopy disturbance creates different ecological conditions in relation to soil, water, humidity, temperature and solar radiation etc. These factors may affect the distribution of herbaceous species. The growth of species in different habitat and association of medicinal plants is important in identifying the suitable habitat and canopy toward future multiplication of the different species. The finding of the present study would be helpful to develop the structure and adequate strategy \& plan for conservation and management of habitats, species and communities for their sustainable utilization.

\section{Declaration}

Ethics approval and consent to participate: Not applicable

Consent for publication: Not applicable

Availability of data and material: The datasets used and or analyzed during the current study are available from the corresponding author on reasonable request.

Competing interests: "The authors declare that they have no competing interests"

Funding: Not applicable

Authors' contributions: PP \& JR participated in the planning and overall design of the study. PP conducted the field measurements and PP and BT did the analysis work. PP prepared the original draft. All authors reviewed and edited the draft and approved the final manuscript. JR supervised the overall work.

Acknowledgements: We are thankful to the Head, Department of Forestry and Environmental Science, Kumaun University Nainital for providing necessary facilities in the department to carry out this research work. 


\section{References}

Ahmad S, Dar HU, Dar JA (2013) Impact of varying disturbances on the structure and composition of grassland vegetation in Anantnag, Kashmir Himalayas. Proceedings of the International. Acad of Ecol and Env Sci 3(3): $219-228$

Altieri MA (1994) Biodiversity and Pest Management Agroecosystems. Haworth Press, New York, USA.

Arya D (2014) Plant species used as traditional agricultural implements and tools in Garhwal region of western Himalaya. Indian J Sci Res and Tech 2(1): 69-72.

Arya N, Tewari B, Ram J (2012) The effect of natural and anthropogenic disturbance in forest canopy and its Effect on Species Richness in Forests of Uttarakhand Himalaya, India. Russ J Ecol 43(2): 117-121. https://doi.org/10.1134/S1067413612020099

Bargali K, Joshi B, Bargali SS, Singh SP (2015) Oaks and the biodiversity they sustain. International Oaks 26:65 76.

Beaman JH, Andresen JW (1966) The vegetation, floristics and phytogeography of the summit of Cerro Potosi, Mexico. American Midland Nat 75(1): 1-33. https://doi.org/10.2307/2423480

Beals EW (1965) Species patterns in a Lebanese Poterietum. Vegetatio Acta Geobot 13: 69-87. https://doi.org/10.1007/BF00241251

Bray JR (1956) A study of mutual occurrence of plant species. Ecol 37(1): 21-28. https://doi.org/10.2307/1929665.

Bruno JF, Stachowicz JJ, Bertness MD (2003) Inclusion of facilitation into ecological theory. Trends in Ecol and Evol 18: 119-125. https://doi.org/10.1016/S0169-5347(02)00045-9.

Burianek V, Novotny R, Hellebrandova K, Sramek V (2013) Ground vegetation as an important factor in the biodiversity of forest ecosystem and its evaluation in regard to nitrogen deposition. J For Sci 59(6): 238252.

Chang CC, Lambers JH (2019) Trait and phylogenetic patterns reveal deterministic community assembly mechanisms on Mount St. Helens. Plant Ecol 220: 675-698. https://doi.org/10.1007/s11258-019-00944-x.

Chesson P (2000) Mechanisms of maintenance of species diversity. Annu Rev Ecol Syst 31: 343-366. https://doi.org/10.1146/annurev.ecolsys.31.1.343. 
Cole LC (1949) The measurement of interspecific association. Ecol 30(4): 411-424. https://doi.org/10.2307/1932444.

Cook CW, Hurst R (1963) A quantitative measure of plant association on ranges in good and poor condition. J Range Manage 15(5): 266-273.

Connor EF, Simberloff D (1979) The assembly of species communities: chance or competition? Ecol 60(6): 11321140. https://doi.org/10.2307/1936961

Correia CMB, Dias ATC, Scarano FR (2010) Plant-plant associations and population structure of four woody plant species in a patchy coastal vegetation of Southeastern Brazil. Revista Braz J Bot 33(4): 607-613. https://doi.org/10.1590/S0100-84042010000400009.

Crawley MJ (1989) Insect herbivores and plant population dynamics. Annu Rev Entomol 34(1): 531-562 Annu Rev of Entomol. https://doi.org/10.1146/annurev.en.34.010189.002531.

Curtis JT, McIntosh RP (1950) The interrelations of certain analytic and synthetic phytosociological characters. Ecol 31: 434-455.

Dice LR (1945) Measures of the amount of ecologic association between species. University of Michigan. Ecol 26(3): 297-302. https://doi.org/10.2307/1932409.

Dixon P (1994) Testing spatial segregation using a nearest-neighbor contingency table. Ecol 75(7):1940-1948. https://doi.org/10.2307/1941598.

Evans FA, Freeman RB (1950) On the relationships of some mammal fleas to their hosts. Ann Entomol Soc Am 43(3): 320-333. https://doi.org/10.1093/aesa/43.3.320.

Farooquee NA, Saxena KG (1996) Conservation and Utilization of medicinal plants in high hills of the central Himalayas. Environ Conserv 23(1): 75-80. https://doi.org/10.2307/44519183.

Gairola S, Sharma CM, Suyal S, Ghildiyal SK (2011) Species composition and diversity in mid- altitudinal moist temperate forests of the Western Himalaya. J For Sci 27(1):1-15.

Goodall DW (1953) Objective methods for the classification of vegetation. I. The use of positive interspecific correlation. Aust J Bot 1(1): 39-63.

Gu L, Gong ZW, Li WZ (2017) Niches and Interspecific associations of dominant populations in three changed stages of natural secondary forests on Loess Plateau, P.R. China. Sci Rep 7(1): 6671. https://doi.org/10.1038/s41598-017-06689-9. 
Hale ME Jr (1955) Phytosociology of corticolous cryptogams in the upland forests of southern Wisconsin. Ecol 36(1): 45-63. https://doi.org/10.2307/1931430.

Hurlbert SH (1969) A coefficient of interspecific association. Ecol Soc of Am 50(1): 1-9. https://doi.org/10.2307/1934657

Hussain MS, Sultana A, Khan JA, Khan A (2008) Species composition and community structure of forest stands in Kumaon Himalaya, Uttarakhand, India. Trop Ecol 49(2): 167-181

Jayakumar S, Kim SS, Heo J. 2011. Floristic inventory and diversity assessment - a critical review. Proc. Int Acad Ecol and Environ Sci 1(3-4): 151-168.

Kharkwal G, Mehrotra P, Pangtey YPS (2005) Comparative studies on species richness, diversity and composition of oak forest in Nainital District, Uttaranchal. Curr Sci 89: 668-672.

Khera N, Kumar A, Ram J, Tewari A (2001) Plant biodiversity assessment in realtion to disturbances in mid elevational forest of central Himalaya, India. Trop Ecol 42(1): 83-95.

Kula AAR, Hey MH, Couture JJ, Townsend PA, Dalgleish HJ (2020) Intraspecific competition reduces plant size and quality and damage severity increases defense responses in the herbaceous perennial, Asclepias syriaca. Plant Ecol 221: 421-430 https://doi.org/10.1007/s11258-020-01021-4

Kumar A (2000) Plant biodiversity in forests of middle central Himalaya in relation to various disturbances. Ph.D. Thesis, Kumaun University, Nainital, India.

Kumar A, Ram J (2005) Anthropogenic disturbances and plant biodiversity in forests of Uttaranchal, central Himalaya. Biodivers and Conserv 14(2): 309-331. http://doi.org/10.1007/s10531-004-5047-4

Macan TT (1954) A contribution to the study of the Corixidae (Hemiptera). J Anim Ecol 23(1): 115- 141. https://doi.org/10.2307/1663.

Macarthur R, Levins R (1967) The limiting similarity, convergence, and divergence of coexisting species. Am Nat 101(921): 377-385.

Maguire B Jr (1963) The passive dispersal of small aquatic organisms and their colonization of isolated bodies of water. Ecol Monogr 33(2): 161-185.

Misra R (1968) Ecology Workbook, Oxford and IBH, Kolkata, 1-242.

Muller-Dombios D, and Ellenberg H (1974) Aims and methods of vegetation ecology. New York: John Wiley and Sons. 
Neumann M, Starlinger F (2001) The significance of different indices for stand structure and diversity in forests. For Ecol and Manag 145(1-2): 91-106 https://doi.org/10.1016/S0378-1127(00)00577-6.

Oliveira JA de, Daniel O, Viera M do C (2007) Spatial distribution pattern and interspecific association of eight medicinal species in the Brazilian Savanna. Cerne 13(1): 111-116.

Pamela G, Martin R, Enrique J (2007) Shifts in positive and negative plant interactions along a grazing intensity gradient. Ecol 88(1): 188-199. https://doi:org/10.1890/0012-9658.

Pandey R, Vibhuti, Karki H, Awasthi P, Bargali K, Bargali SS (2018) Effect of wildfire on herbaceous vegetation in cypress mixed Oak forest of Nainital, Kumaun Himalaya, India. Curr Tren For Res. CTFR-121. https://doi.org/10.29011/2638-0013.

Petriccione B (2002) Survey and assessment of vegetation in the CONECOFOR permanent plots. In: MOSELLOV., PETRICCIONE B., MARCHETTO A. (eds): Long-term ecological research in Italian forests ecosystems. $\mathrm{J}$ of limnol, 61(1s): 19-24.

Philips EA (1959) Methods of vegetation study. Henry Holt and Co. Inc., New York.

Pielou EC (1961) Segregation and symmetry in two-species populations as studied by nearest-neighbour relationships. J of Ecol 49(2): 255-269. https://doi.org/10.2307/2257260.

Prasad P, Ram J (2017) Plant biodiversity across different canopy covers of Quercus leucotrichophora A. Camus Forest in Central Himalaya. ENVIS Bulletin Himal Ecol 25: 106-110.

R Macarthur, R Levins (1967) The limiting similarity, convergence, and divergence of coexisting species. Am Nat 101(921): 377-385. Am Nat. https://doi.org/10.1086/282505

Ram J, Kumar A, Bhatt J (2004) Plant diversity in six forest types of Uttaranchal, Central Himalaya, India. Curr Sci 86(7): 975-978.

Rathore SKS, Singh SP, Singh JS, Tiwari AK (1997) Changes in forest cover in a central Himalayan catchment: inadequacy of assessment based on forest area alone. J of Environ Manage 49(3): 265-276. https://doi.org/10.1006/jema.1995.0096

Ratliff R.D (1982) A correction of Cole's C7 and Hurbert's C8 coefficients of interspecific association. Ecol Washington 63(5): 1605-1606

Raunkiaer C (1934) The Life Forms of Plants and Statistical Plant Geography. Clarendon Press, Oxford. pp 632. 
Rikhari HC, Chandra R, Singh SP(1989) Pattern of species distribution and community characters along a moisture gradient within an oak zone of Kumaun Himalaya. Proc Indian Nat Sci Acad 55(B): 431-438.

Salemaa M, Hamberg L (2007) Understory vegetation on level II plots during 1998-2004. In: MERILA P., KILPONEN T., DEROME J. (eds): Forest Condition Monitoring in Finland-Na, Finnish Forest Research Institute: 69-80.

Sati VP, Bandooni SK (2018) Forests of Uttarakhand: Diversity, Distribution, Use Pattern and Conservation. ENVIS Bulletin Himal Ecol, 26: 21-27.

Sanjerehei MM, Rundel PW (2020) A Comparison of methods for detecting association between plant species. Ecol Informat 55:101034. https://doi.org/10.1016/j.ecoinf.2019.101034

Saxena AK, Singh JS (1982) A Phytosociological analysis of woody species in forest communities of a part of Kumaun Himalaya. Veget 50(1): 3-22. https://doi.org/10.1007/BF00120674

Saxena AK, Singh SP, Singh JS (1984) Population structure of forests of Kumaun Himalaya: implication for management. J of Environ manage 19(4): 307-324.

Schluter D (1984) A variance test for detecting species associations, with some example applications. Ecol 65(3): 998-1005. https://doi.org/10.2307/1938071

Schoenly KG, Zhang WJ (1999) IRRI Biodiversity Software Series. V. RARE, SPPDISS, and SPPANK: programs for detecting between-sample difference in community structure. IRRI Technical Bulletin No. 5. International Rice Research Institute, Manila, Philippines.

Seidling W (2005) Ground floor vegetation assessment within the intensive (level II) monitoring of forest ecosystems in Germany: chances and challenges. Eur J of For Res 124(4): 301-312. https://doi.org/10.1007/s10342$\underline{005-0087-1}$

Singh G, Padalia H, Rai ID (2016) Spatial extent and conservation status of Banj oak (Quercus leucotrichophora A. Camus) forests in Uttarakhand, Western Himalaya. Trop Ecol 57(2): 255-262.

Singh JS, Singh SP (1984) An Integrated Ecological Study of Eastern Kumaun Himalaya with Emphasis on Natural Resources. 1 (3), Final Report (HCS/DST/187/76). Kumaun University, Nainital.

Singh JS, Singh SP (1992) Forests of Himalaya: Structure, Functioning and Impact of Man, Gyanodaya Prakashan, Nainital. 
Singh SP, Adhikari BS, Zobel DB (1994) Biomass, productivity, leaf longevity, and forest structure in the central Himalaya. Ecol Monogr 64(4): 401-421. https://doi.org/10.2307/2937143

Smith BE, Cottam G (1967) Spatial relationships of mesic forest herbs in southern Wisconsin. Ecol 48(4): 546-558. https://doi.org/10.2307/1936498

Snedecor GW, Cochran WG (1967) Statistical Methods. Oxford and IBM, New Delhi, 381-418.

Stang M, Klinkhamer PGL, van der Meijden E (2007) Asymmetric specialization and extinction risk in plant-flower visitor webs: a matter of morphology or abundance? Oecologia 151(3): 442-453. https://doi.org/10.1007/s00442-006-0585-y

Tewari JC, Singh SP (1985) Analysis of woody vegetation in a mixed oak forest Kumaun Himalaya. Proc Indian Nat Sci Acad 51(B): 332- 347.

Tiwari OP, Rana YS, Krishan R, Sharma CM, Bhandari BS (2018) Regeneration dynamics, population structure, and forest composition in some ridge forests of the Western Himalaya, India. For Sci and Techn. 14(2): 66-

\section{5. https://doi.org/10.1080/21580103.2018.1447517}

Upreti NJ, Tewari JC, Singh SP (1985) The Oak forests of Kumaun Himalaya India: composition, diversity and regeneration. Mt Res and Deve 5(2): 163-174. https://doi.org/10.2307/3673255

Valdiya KS (1980) Stratigraphic scheme of the sedimentary units of the Kumaun Lesser Himalaya. In: Valdiya KS, Bhatiya SB (eds) Stratigraphy and Correlations of the Lesser Himalayan Formations. Hindustan Publication Corporation, Delhi, India 7- 48.

Vasilevich VI (1961) Association between species and the structure of a phytocoenosis. Akad. Nauk SSSR. Doklady: Bot Sci Sect 139: 1001-1004.

Vasilevich VI (1963) Application of partial associations for analysis of the structure of plant communities. Akad. Nauk SSSR. Doklady: Biol Sci Sect.148: 214-216.

Weiher E, Clarke GDP, Keddy PA (1998) Community assembly rules, morphological dispersion, and the coexistence of plant species. Oikos 81(2): 309-322. https://doi.org/10.2307/3547051.

Yang QW, Liu SJ, Hu CH, Lin YB, Zhang B, Luo ML, Peng HL (2016) Ecological species groups and interspecific association of vegetation in natural recovery process at Xiejiadian landslide after 2008 Wenchuan earthquake. J of Mou Sci13(9): 1609-1620. https://doi.org/10.1007/s11629-016-3807-8 
Yuan Z, Gazol A, Lin F, Wang X, Ye J, Suo Y, Fang S, Mellard J, Hao Z (2016) Scale-dependent effect of biotic interactions and environmental conditions in community assembly: insight from a large temperate forest plot. Plant Ecol 217(8): 1003-1014. https://doi.org/10.2307/24751098.

Zhang WJ (2007) Computer inference of network of ecological interactions from sampling data. Environ Monit Assess 124(1-3): 253-261. https://doi.org/10.1007/s10661-006-9223-8

Zhang WJ (2011) Constructing ecological interaction networks by correlation analysis: hints from community sampling. Net Biol 1(2): 81-98.

Zhang WJ (2012a) Computational Ecology: Graphs, Networks by Agents-based Modeling. World Scientific, Singapore.

Zhang WJ (2012b) How to construct the statistic network? An association network of herbaceous plants constructed from field sampling. Net Biol 2(2): 57-68.

Zhang WJ (2014) Interspecific associations and community structure: A local survey and analysis in a grass community. Selforganizology, 1(2): 89-129. 
Figures

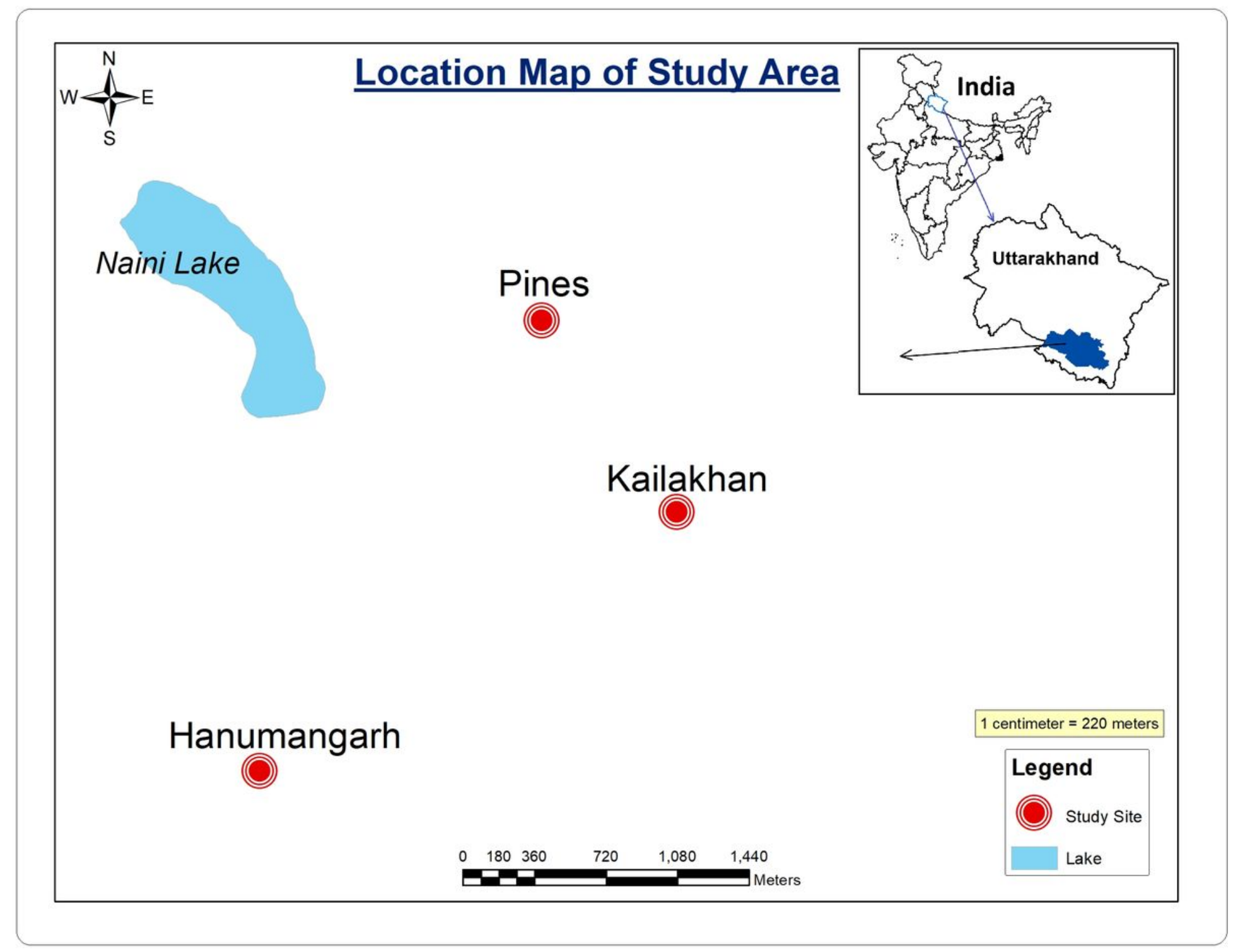

Figure 1

Location map of the study area Note: The designations employed and the presentation of the material on this map do not imply the expression of any opinion whatsoever on the part of Research Square concerning the legal status of any country, territory, city or area or of its authorities, or concerning the delimitation of its frontiers or boundaries. This map has been provided by the authors. 


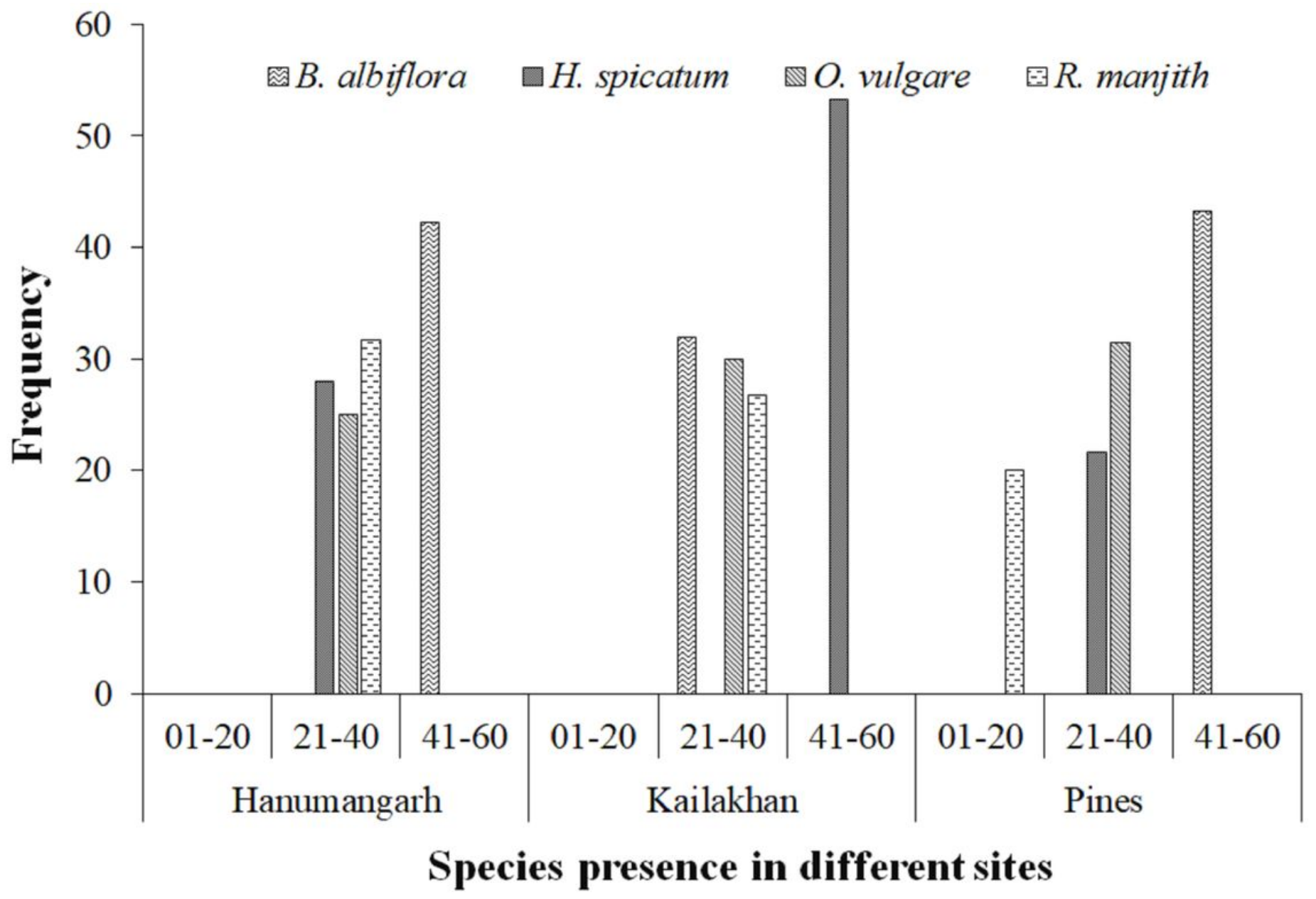

Figure 2

Frequency (Presence-absence) of four medicinally important plants in different Sites 1-20 Rare, 21-40 Seldom present, 41-60 Often present 


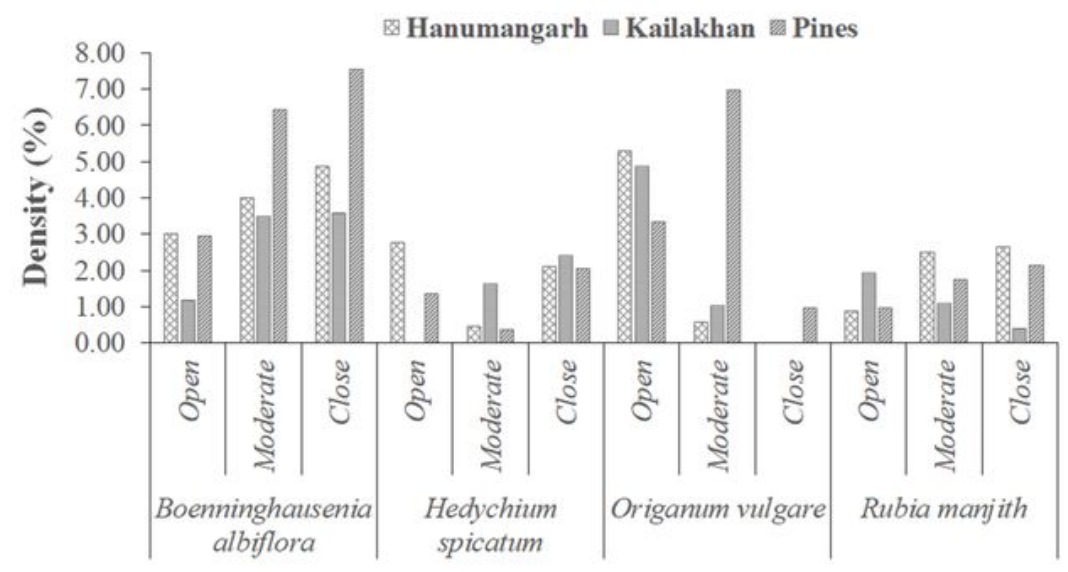

Species in different canopy class

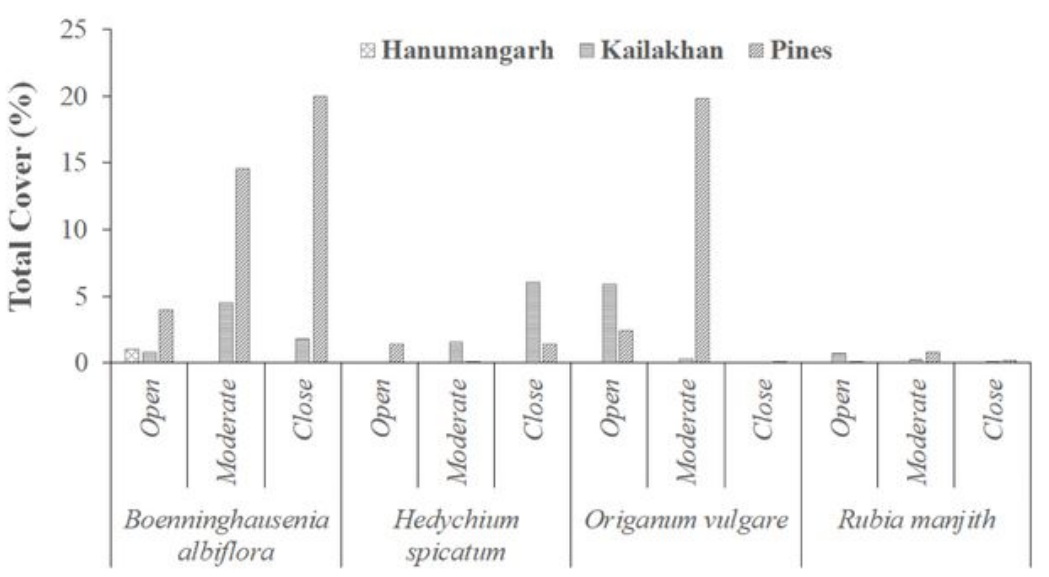

Species in different canopy class

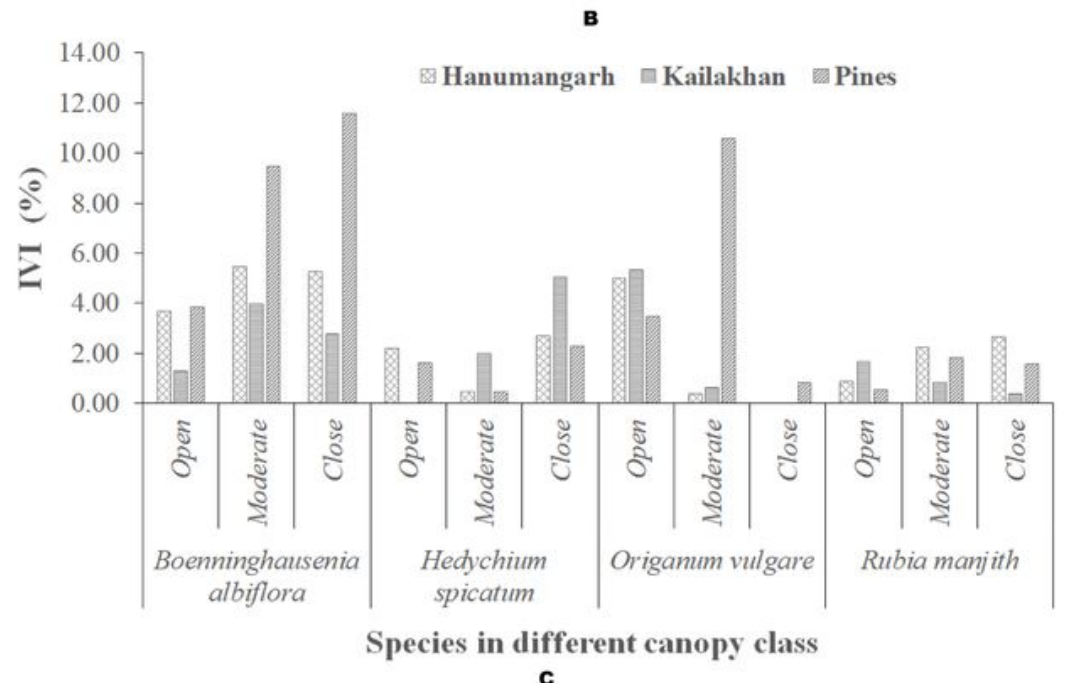

\section{Figure 3}

The Percent (a) Density (b) Total cover (c) IVI of medicinal plants to the total vegetation in different sites and canopy class

\section{Supplementary Files}


This is a list of supplementary files associated with this preprint. Click to download.

- Table05.10.2020.docx 